\title{
Subacute combined degeneration of the cord due to folate deficiency: response to methyl folate treatment
}

\author{
EG LEVER,* RDC ELWES, $\dagger$ A WILLIAMS $\ddagger$ EH REYNOLDS $\dagger$
}

From the Departments of Medicine, ${ }^{*}$ Neurology $†$ and Haematology $\ddagger$ Kings College Hospital, London, UK

SUMMARY Subacute combined degeneration of the cord is a rare complication of folate deficiency. Disturbance of methylation reactions in nervous tissue probably underlie subacute combined degeneration of the cord arising from folate as well as vitamin $\mathbf{B}_{12}$ deficiency. Methyl tetrahydrofolate is the form in which folic acid is transported into the CNS. Therefore methyl tetrahydrofolate treatment of the neurological and psychiatric manifestations of folate deficiency would seem to be theoretically advantageous. A case of subacute combined degeneration of the cord due to dietary folate deficiency and associated with an organic brain syndrome is reported. There was striking haematological, neurological and psychiatric response to methyl folate treatment.

Subacute combined degeneration of the spinal cord is a rare complication of folate deficiency. In a review of 25 previously reported cases ${ }^{1}$ prior to 1979 five met the following criteria:- pyramidal and dorsal column signs, low serum and red cell (or CSF) folate, megaloblastic marrow, normal vitamin $B_{12}$ levels of absorption, and reversibility of neurological signs by folate, but not vitamin $\mathbf{B}_{12}$ (table 1). Histopathological confirmation of subacute combined degeneration of the cord due to folate deficiency has been reported since then in an alcoholic, ${ }^{2}$ and in a child with pure folate deficiency due to an inborn error of folate metabolism as a result of methylene tetrahydrofolate reductase deficiency. ${ }^{3}$

Methyl folate is the reduced form of folate in blood. Separate transport mechanisms exist for the transport of reduced and non-reduced folates into intestinal cells. ${ }^{4}$ Transport of reduced folate is active, energy-dependent, and carrier-mediated and several fold greater than that of non-reduced folates. Folic acid crosses the blood brain barrier as methyl tetrahydrofolate by an active process, ${ }^{5}$ and is present in CSF in man in concentrations three times greater than plasma. ${ }^{6}$ Treatment of folate deficiency-induced

Address for reprint requests: Dr EH Reynolds, Kings College Hospital, Denmark Hill, London SE5 9RS, UK.

Received 30 July 1985 and in revised form 7 January 1986. Accepted 3 February 1986 neuropsychiatric disorders by methyl folate, the transport form of folate into the nervous system, would thus appear to be theoretically advantageous.

We describe a case of subacute combined degeneration of the cord due to folate deficiency which responded to treatment with methyl folate. In addition the patient had an organic brain syndrome which also responded in part to methyl folate therapy.

\section{Case report}

JD, a 53-year-old woman, presented with a 2 year history of progressive leg weakness, paraesthesiae of hands and feet, dyspnoea on exertion, and six months confusion. She had a 15 year history of alcohol abuse and 10 years of intermittent depression. Two years previously she had been investigated for lethargy and had been noted to have spider naevi and liver palms, an MCV of 105, and normal serum folate and vitamin $B_{12}$ levels. On examination she was anaemic, apathetic, confused, with poor concentration, and confabulating. She was disoriented in time and place. She had horizontal nystagmus, an ataxic broad based gait, symmetrical grade 3 pyramidal weakness of her legs, absent knee and ankle reflexes and bilateral extensor plantar responses.

Investigations confirmed she had a macrocytic anaemia: $\mathrm{Hb} 9 \mathrm{gm} / \mathrm{dl}$, MCV 126, with a megaloblastic marrow. Serum vitamin $\mathrm{B}_{12}$ on admission was $775 \mathrm{ng} / \mathrm{l}$ (N 200-800) but serum folate $(0.7 \mathrm{ng} / \mathrm{ml})$, red cell folate $(68 \mathrm{ng} / \mathrm{ml})$ (N200-800) and CSF folate $5 \mathrm{ng} / \mathrm{ml}(\mathrm{N}>15)$ were all very low. CSF S-adenosyl-methionine (SAM) was $37 \cdot 7 \mathrm{ng} / \mathrm{ml}$ (control range 35-90. The control range is derived from a study of 24 severely depressed patients $25 \%$ of whom also had severe folate deficiency. The mean for the group was 55 (S.D. 14.5) $\mathrm{ng} / \mathrm{ml}$. The CSF SAM level of 37.7 in our patient 
Table Summary of aetiological, neurological, haematological data and treatment responses in reported cases of subacute combined degeneration of the cord due to folate deficiency

\begin{tabular}{|c|c|c|c|c|c|c|c|c|c|c|c|}
\hline \multirow[t]{2}{*}{ Source } & \multirow{2}{*}{$\begin{array}{l}\text { Aetiological } \\
\text { factors }\end{array}$} & \multicolumn{4}{|c|}{ Neurological signs } & \multirow{2}{*}{$\begin{array}{l}\text { Serum } \\
\text { folate } \\
\text { ng } / \mathrm{ml}\end{array}$} & \multirow{2}{*}{$\begin{array}{l}\text { Megalo- } \\
\text { blastic } \\
\text { marrow }\end{array}$} & \multirow{2}{*}{$\begin{array}{l}\text { Schilling } \\
\text { test }\end{array}$} & \multirow{2}{*}{$\begin{array}{l}\text { Serum } \\
B_{12} \\
n g / l\end{array}$} & \multirow{2}{*}{$\begin{array}{l}\text { Response } \\
\text { to } B_{12}\end{array}$} & \multirow{2}{*}{$\begin{array}{l}\text { Response } \\
\text { to folate }\end{array}$} \\
\hline & & $D T R$ & Babinski & Sensation & Dementia & & & & & & \\
\hline $\begin{array}{l}\text { Ahmed } \\
\text { Pincus } \text { et } a l^{11}\end{array}$ & $\begin{array}{l}\mathrm{D} \\
\mathrm{A}\end{array}$ & $\begin{array}{l}+ \\
-v e\end{array}$ & $\begin{array}{l}\uparrow \uparrow \\
, "\end{array}$ & $\begin{array}{l}\text {-ve } \\
\text {-ve }\end{array}$ & $\bar{t}$ & $\begin{array}{l}0.6 \\
1.0 \\
(\text { CSF 4.6) }\end{array}$ & $\begin{array}{l}\mathbf{M} \\
\mathbf{M}\end{array}$ & $\overline{\mathrm{N}}$ & $\begin{array}{l}300 \\
2000\end{array}$ & $\begin{array}{l}\text {-ve } \\
\text { - ve }\end{array}$ & $\begin{array}{l}\mathrm{H}+\mathrm{NR} \\
\mathrm{H}+\mathrm{NR}\end{array}$ \\
\hline LePrize et $a l^{12}$ & A & $\underset{-\mathrm{AJ}-)^{+}}{+}$ & ", & - ve & - & 1.0 & $\mathbf{M}$ & $\mathbf{N}$ & 400 & - ve & $\mathbf{H}+\mathbf{N R}$ \\
\hline $\begin{array}{l}\text { Mauffroy et } a l^{13} \\
\text { Manzoor \& }\end{array}$ & A & & , & - ve & - & $3 \cdot 6$ & $-N / A$ & $\mathbf{N}$ & - & - ve & $\mathbf{H}+\mathbf{N R}$ \\
\hline $\begin{array}{l}\text { Runcie } \\
\text { Guard } \text { et }^{14}{ }^{2}\end{array}$ & $\begin{array}{l}\mathrm{D} \\
\mathrm{A}\end{array}$ & $\begin{array}{l}-\mathrm{ve} \\
-\mathrm{ve}\end{array}$ & ", & $\frac{-v e}{N / A}$ & $\begin{array}{l}+ \\
-\end{array}$ & $\begin{array}{l}1 \cdot 0 \\
0.9 \\
(\mathrm{RBC} 56)\end{array}$ & $\begin{array}{l}-\mathbf{N} / \mathbf{A} \\
-\mathbf{N} / \mathbf{A}\end{array}$ & - & $\begin{array}{l}340 \\
445\end{array}$ & - ve & $\begin{array}{l}\text { NR } \\
\text { Died (SACD } \\
\text { at PM) }\end{array}$ \\
\hline Present report & $\mathbf{A}$ & - ve & , & - ve & + & $\begin{array}{l}0.7 \\
\text { (RBC 68) } \\
(\text { CSF 5) }\end{array}$ & $\mathbf{M}$ & $\mathbf{N}$ & 775 & - ve & $\mathrm{H}+\mathrm{NR}$ \\
\hline
\end{tabular}

Key: D = Diet; $\mathrm{A}=$ Alcohol + Poor diet; DTR $=$ Deep Tendon Reflexes; $\mathbf{M}=$ Megaloblastic; N/A $=$ Not available; $+=$ Present; - ve $=$ Absent; $\mathbf{N}=$ Normal; $-\mathbf{~ = ~ N o t ~ r e p o r t e d ; ~} \mathbf{H}=$ Haematological Remission; $\mathbf{N R}=$ Neurological remission.

is therefore one of the lowest observed.) Her ESR was $126 \mathrm{~mm} / \mathrm{hr}$. Red cell transketolase was $8 \mathrm{IU} / \mathrm{l}$ (N 35-90) with thiamine pyrophosphate effect of $72 \%$, confirming thiamine deficiency. Liver function was normal except gamma glutamyl transpeptidase which was $95 \mathrm{IU} / 1(\mathrm{~N}<45)$.

Electrophysiological studies (Dr J Payan) revealed that surface recorded sural nerve potentials had an amplitude of $5 \mu \mathrm{V}$, which is half the normal minimum for this laboratory. The median nerve sensory potential recorded at the wrist on stimulating the middle finger was only $7 \mu \mathrm{V}$, which was less than half our normal minimum and smaller than the corresponding ulnar potential $(8 \mu \mathrm{V})$. This reversal of the normal relationship almost certainly reflected added local median nerve damage at the wrist, for the distal motor latency to thenar muscles was increased $(4.7 \mathrm{~ms}$, normal does not exceed $4.0 \mathrm{~ms}$; hypothenar potential latency in this case $3.1 \mathrm{~ms}$ ). Moreover, the median mixed nerve potential recorded at the elbow was markedly reduced $(4 \mu \mathrm{V}$, normal minimum $20 \mu \mathrm{V}$; ulnar mixed potential in this case $27 \mu \mathrm{V}$, normal minumum $30 \mu \mathrm{V}$ ). The amplitude and form of evoked muscle potentials was normal, but the hypothenar potential was $25 \%$ smaller on stimulating above the elbow than at the wrist. The abductor hallucis potential had a slightly increased $F$ wave latency $(59 \mathrm{~ms})$. In brief, nerve conduction studies show a mild mixed, predominantly sensory, polyneuropathy of axonal type with added damage, as is common, to the median nerve at the wrist and the ulnar nerve at the elbow.

Investigations to exclude other causes of myelopathy were performed. Serum and CSF TPHA, and VDRL were negative. CSF protein, immunoglobulins and cell count were normal, and oligoclonal bands were absent. Visual evoked responses were normal. Radiographs of the cervical spine were normal. CT scan demonstrated dilated ventricles and widened sulci indicative of moderate cortical atrophy. EEG revealed non-specific diffuse bilateral slow wave abnormalities. Psychometry showed generalised intellectual, verbal and visual memory impairment, with severe short term memory impairment. Wechsler Adult Intelligence Score
(WAIS) was:- verbal 86 , performance 91 , full scale 87 , predicted 103. Further investigations did not reveal any evidence of malabsorption. Small bowel study, Schilling test, glucose tolerance test, three day faecal fat and urinary indicans were within normal limits. Stool culture did not reveal any pathogens. Dietary questionnaire confirmed a very low intake of folate containing foodstuffs.

Her clinical course is shown in the fig. In view of the acute confusional state and nystagmus suggestive of Wernicke's encephalopathy she was initially treated with parenterovite for the first $\mathbf{1 0}$ days after admission. Her nystagmus disappeared, and her confusion diminished. During the first week she also received three injections of $1000 \mu \mathrm{g}$ of hydroxycobalamin. Although the reticulocyte count rose to $15 \%$ ten days after admission, there was no further change in wellbeing or reversal of the megaloblastic changes in her marrow 3 weeks after admission. She was left with a residual apathetic amnesic state. The pyramidal weakness, ataxia and arreflexia were unchanged. Sensory examination at this time also revealed complete absence of vibration sense up to and including the iliac crests and impaired joint position sensation in both feet and ankles. There was no sensory abnormality in the upper limbs.

Four weeks after admission she was given methyl folate $15 \mathrm{mg}$ daily by mouth. Within one week there was marked improvement in her mood, alertness and well-being. Within two weeks of methyl folate therapy there was marked improvement in pyramidal weakness (grade 4-5). Marrow examination at this time was normoblastic. Serum folate had risen to $20 \mathrm{ng} / \mathrm{ml}$, red cell folate to $1000 \mathrm{ng} / \mathrm{ml}$ and CSF folate to $10 \mathrm{ng} / \mathrm{ml}$. CSF SAM was $41.8 \mathrm{ng} / \mathrm{ml}$. Follow-up psychometry at 6 weeks showed marked improvement of all parameters except verbal memory. WAIS scores were:verbal $101(+15)$, performance $97(+6)$, full scale $99(+12)$. Short term memory was improved but remained poor. Her EEG was now normal. After 10 weeks power in her legs was normal, but lower limb reflexes remained absent and plantar responses extensor. Vibration sensation had returned to the iliac crests and knees, and was 3 seconds at the ankles. Joint 


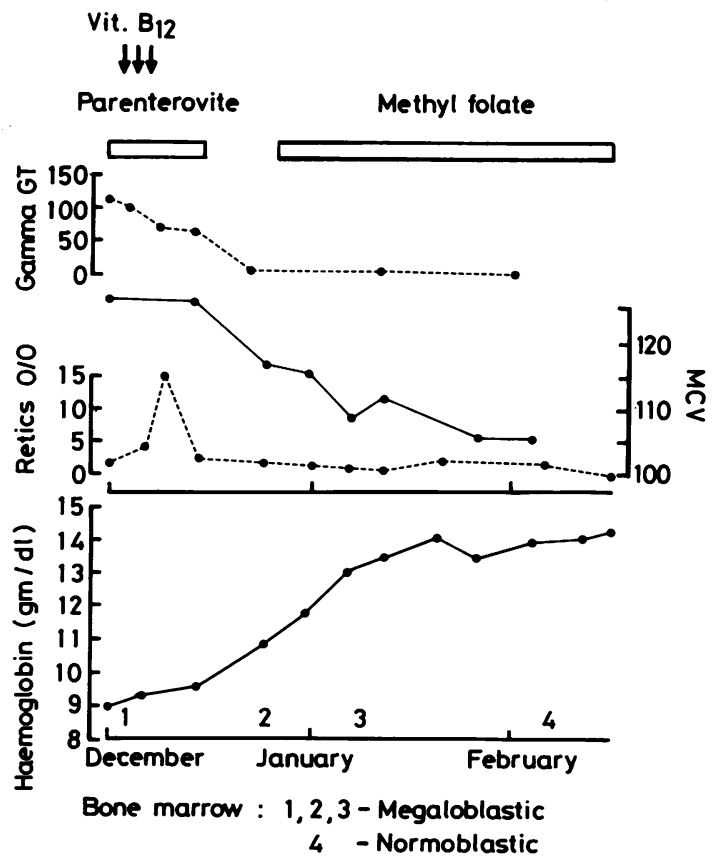

Fig Haematological and biochemical response to treatment with parenterovite, vitamin $B_{12}$ and methyl folate.

position sense was normal. EMG studies at 10 weeks showed evidence of improvement of the associated neuropathy.

\section{Discussion}

The unique features of the present case report are our use of methyl-tetrahydrofolate for treatment and the impressive and rapid haematological, neurological and psychiatric response.

The evidence clearly indicated that megaloblastic anaemia in this patient was due to folate deficiency. Serum, red cell and CSF folate were all very low. Serum vitamin $\mathbf{B}_{12}$ levels were high normal and there was no evidence of folate or vitamin $B_{12}$ malabsorption. Following three initial vitamin $B_{12}$ injections there was no evidence of haematological or neurological remission, and her marrow was still megaloblastic after 3 weeks. The early reticulocyte rise was almost certainly due to a combination of withdrawal from alcohol, which is well described, ${ }^{78}$ and the introduction of folate in her hospital diet (approximately $200-400 \mu \mathrm{g} / \mathrm{day}$ ). Following treatment with methyl folate the patient's bone marrow rapidly became normoblastic and recovery in blood count was accelerated (fig).

Neuropsychiatric complications are as commonly associated with megaloblastic anaemia due to folate deficiency as they are with anaemia due to vitamin $B_{12}$ deficiency. ${ }^{9}$ However, spinal cord complications of folate deficiency are relatively rare. Six cases of subacute combined degeneration of the cord are summarised in the table. ${ }^{210-14}$ Neuropathological verification of subacute combined degeneration of the cord due to an inborn error of folate metabolism has been conclusively demonstrated in a further case. ${ }^{3}$ The importance of this patient is that there was no other vitamin deficiency or alcohol implicated. In our patient there was striking improvement in motor and sensory function following treatment with methyl folate. In addition to the improvement of her cord signs there was also EMG confirmation of improvement in the neuropathy which frequently accompanies subacute combined degeneration of the cord. Possible reasons why subacute combined degeneration of the cord due to folate deficiency is uncommon are: the concentration of folate in CSF and presumably in CNS is 2-3 times that of serum; ${ }^{6}$ and the fact that some examples may be overlooked because of the widespread misconception that all cases of subacute combined degeneration of the cord are due to vitamin $\mathrm{B}_{12}$ deficiency. ${ }^{1}$

The psychiatric response to methyl folate in our patient should be interpreted with caution. She clearly had more than one deficiency state and had initially received both parenterovite and vitamin $\mathbf{B}_{12}$. Certainly the early improvement in her mental state especially her initial confusion was due at least in part to repletion of thiamine as well as dietary factors, including folate. However one month after thiamine and vitamin $B_{12}$ therapy she remained flat, apathetic and globally impaired and the subsequent rapid change in mood and cognition after methyl folate strongly suggested that a large contribution of her residual organic mental impairment was due to severe folate deficiency. This is supported by a number of lines of evidence. Studies of neuropsychiatric and geriatric patients have linked severe folate deficiency to organic mental states, especially endogenous depression. ${ }^{1516}$ Inborn errors of folate metabolism are associated with mental retardation, ${ }^{17}$ and methotrexate, a tetrahydrofolate reductase inhibitor, has been reported to cause acute organic mental disturbance. ${ }^{18}$ It is interesting that in this patient CSF SAM level was initially low and increased slightly but significantly following two weeks of methyl folate in association with impressive changes in mood and cognition. Recent studies have shown improvement in mood following SAM therapy in some patients with endogenous depression. ${ }^{1920}$

The role of alcohol should also be considered. Firstly the patient was an alcoholic on a folate deficient diet similar to four out of the six previous reports summarised in the table. Secondly in a survey 
of patients with Korsakoff's psychosis, almost all of whom were alcoholic, Victor et $a^{21}$ reported that $39 \%$ had megaloblastic anaemia associated with folate deficiency. Alcohol may interfere with folate metabolism in a number of ways: inhibition of tetrahydrofolate reductase; ${ }^{22}$ reduction in folate absorption, ${ }^{23}$ although disputed by Klipstein and Lindenbaum; ${ }^{24}$ reduction in liver storage, ${ }^{25}$ increased urinary excretion, ${ }^{26}$ and interference with the enterohepatic folate cycle. ${ }^{27}$ In addition alcohol may have a direct toxic effect on marrow. In our patient there was no evidence of vacuolation or ringed sideroblasts to support this. In a study of the neuropsychiatric associations of severe folate deficiency in a general medical ward setting, organic mental impairment and pyramidal tract damage were found whether or not the deficiency was associated with alcoholism. ${ }^{28}$ Interestingly chronic alcoholism was a well recognised cause of subacute combined degeneration of the cord in the first half of the century ${ }^{29}{ }^{30}$ prior to the discovery of folic acid and vitamin $B_{12}$ in the 1940s.

The possibility of an alcohol-related myelopathy associated with natural or artificial portosystemic shunts was considered. However this myelopathy is characterised by spastic tone, hyperreflexia and flexor plantars. ${ }^{31}$ In our patient tone was normal, knees and ankle reflexes were initially absent and plantars were extensor. Moreover there was no splenomegaly, varices or ascites and the impressive recovery of the myelopathy would also be against such an interpretation.

In view of the frequency of folate deficiency in alcoholic patients, the role of this vitamin in the neuropsychiatric disorders of alcoholism would repay further study. There is also evidence in the rat that pure folate deficiency leads to malabsorption of thiamine. ${ }^{32}$ Transport of ${ }^{35} \mathrm{~S}$-thiamine was significantly reduced in folate and thiamine deficient malnourished alcoholics. ${ }^{33}$ Learning deficits in folate deficient rats were reversible with either folic acid or thiamine. ${ }^{34}$ These observations may be important in view of the finding of thiamine deficiency in our patient and the association of alcoholism, folate deficiency and Korsakoff's psychosis. ${ }^{21}$

Methyl folate plays a regulatory role in numerous methylation reactions in the nervous system. This occurs via the synthesis of methionine (and ultimately SAM) by the enzyme methionine synthetase which requires vitamin $B_{12}$ as a co-factor. ${ }^{35}$ Nitrous oxide, which seriously impairs the function of methionine synthetase, can produce experimental subacute combined degeneration in monkeys. ${ }^{36}$ Nitrous oxideinduced lesions occur after several weeks and can be prevented by prior treatment with methionine. Cycloleucine, a SAM antagonist, has also been reported to produce lesions resembling subacute com- bined degeneration of the cord in mice after a few days. ${ }^{37}$ Nitrous oxide and cycloleucine models both suggest that disturbance in methylation in the nervous system may underlie the subacute combined degeneration of the cord of vitamin $\mathbf{B}_{12}$ and folic acid deficiency. It is already accepted that a common mechanism involving nucleoprotein synthesis underlies the megaloblastosis of both deficiencies. ${ }^{38}$ From the above and other evidence it seems likely that the mechanism underlying the neurological complications of both deficiency states is also similar. ${ }^{39}$

The encouraging response of our patient to methyl folate suggests that further studies of its use are indicated.

We are grateful to Dr P Payan for the electrophysiological studies and to BioResearch, Milan for providing methyl folate.

\section{References}

${ }^{1}$ Pincus JH. Folic acid deficiency: a cause of subacute combined system degeneration. In: Botez MI, Reynolds EH, eds. Folic Acid in Neurology, Psychiatry, and Internal Medicine. New York: Raven Press, 1979:427-34.

${ }^{2}$ Guard O, Dumas R, Audry D, Tommasi M, Knopf JF. Etude anatomo-clinique d'un cas de dégénérescence combinée sub aiguë médullaire au cous dure carense en acide folique. Rev Neurol (Paris) 1981;137:435-46.

${ }^{3}$ Clayton P, Smith I, Harding B, Hyland K, Leonard JV. Subacute combined degeneration of the cord, dementia and Parkinsonism due to an inborn error of folate metabolism. J Neurol Neurosurg Psychiat (in press).

${ }^{4}$ Huennekens FM, Vitols KS, Henderson GB. Transport of folate compounds in bacterial and mammalian cells. Adv Enzymol Related Areas of Molecular Biology 1978;47:313-46.

${ }^{5}$ Spector R, Lorenzo AV. Folate transport in the central nervous system. Am J Physiol 1975;229:777-82.

${ }^{6}$ Reynolds EH, Gallagher BB, Mattson RH, Bowers M, Johnson AL. Relationship between serum and CSF folate. Nature 1972;240:155-157.

${ }^{7}$ Wintrobe MM, Schumacker HS. The occurrence of macrocytic anaemia in association with disorders of the liver together with a consideration of the relationship of this anaemia to pernicious anaemia. Bull Johns Hopkins Hosp 1933;52:387-407.

${ }^{8} \mathrm{Jandl} \mathrm{JH}$. The anaemia of liver disease: observations on its mechanism. J Clin Invest 1955;34:390-404.

${ }^{9}$ Shorvon SD, Carney MWP, Chanarin I, Reynolds EH. The neuropsychiatry of megaloblastic anaemia. $\mathrm{Br} \mathrm{Med}$ $J$ 1980;281:1036-43.

${ }^{10} \mathrm{Ahmed} \mathrm{M}$. Neurological disease and folate deficiency. $\mathrm{Br}$ Med J 1972;1:181.

${ }^{11}$ Pincus JH, Reynolds EH, Glaser GH. Subacute combined system degeneration with folate deficiency. JAMA 1972;221:496-7. 
${ }^{12}$ LePrize PY, Boutin J, Menault F, Richier JC. Carence en acide folique et sclerose combinée de la moelle. Sem Hop Paris 1974;50:2325-6.

${ }^{13}$ Mauffroy B, Zittoun J, Barrois A, Poisson M, Zittoun R. Carences en folates et troubles neurologiques. Sem Hop Paris 1975;51:237-41.

${ }^{14}$ Manzoor M, Runcie J. Folate responsive neuropathy: report of 10 cases. $\mathrm{Br}$ Med J 1976;1:1176-8.

${ }^{15}$ Reynolds EH. Neurological aspects of folate and vitamin $\mathrm{B}_{12}$ metabolism. In: Hoffbrand $\mathrm{AV}$, ed. Clinics in Haematology 1976;5:661-96.

${ }^{16}$ Reynolds EH, Stramentinoli G. Folic acid, S-adenosylmethionine and affective disorder. Psychol Med 1983;13:705-10.

${ }^{17}$ Niederwieser A. Inborn errors of pterin metabolism. In: Botez MI, Reynolds EH, eds. Folic Acid in Neurology, Psychiatry, and Internal Medicine. New York: Raven Press, 1979:349-84.

${ }^{18}$ Kay HEM, Knapton PJ, O'Sullivan JP, Wells DG, Harris RF, Innes EM, Stuart J, Schwartz FCM, Thompson EN. Encephalopathy in acute leukaemia associated with methotrexate therapy. Arch Dis Child 1972; 47:344-54.

${ }^{19}$ Agnoli A, Andreoli V, Casacchia M, Cerbo R. Effect of S-adenosyl L-methionine (SAMe) upon depressive symptoms. J Psychiatr Res 1976;13:43-54.

${ }^{20}$ Reynolds EH, Carney MWP, Toone BK. Methylation and mood. Lancet 1984;2:196-8.

${ }^{21}$ Victor M, Adams RD, Collins GH. The WernickeKorsakoff Syndrome. Oxford, Blackwell, 1971.

${ }^{22}$ Bertino JR, Huenneken F. (eds) Folate Antagonists as Chemotherapeutic Agents. Ann New York Acad Sci 1971:186.

${ }^{23}$ Halsted GH, Griggs RC, Harris JW. The effect of alcoholism on the absorption of folic acid $\left({ }^{3} \mathrm{H}\right.$ PGA) evaluated by plasma levels and urine excretion. $J$ Lab Clin Med 1967;69:116-31.

${ }^{24}$ Klipstein FA, Lindenbaum J. Folate deficiency in chronic liver disease. Blood 1965;25:443-56.

${ }^{25}$ Leevy CM, Baber H, Tehore W, Frank O, Cherrick GR. B-complex vitamins in liver disease of the alcoholic. Am J Clin Nutr 1965;16:339-46.

${ }^{26}$ Carter FC, Heller P, Schaffer G, Korn PJ. For- miminoglutamic acid (FIGLU) excretion in hepatic cirrhosis. Arch Int Med 1961;108:41-6.

${ }^{27}$ Hillman RS. Alcohol interference with the folate enterohepatic cycle. Trans Assoc Physicians 1977;90:145-56.

${ }^{28}$ Reynolds EH, Rothfeld P, Pincus J. Neurological disease associated with folate deficiency. $\mathrm{Br}$ Med $J$ 1973;ii:398-400.

${ }^{29}$ Nonne $M$. Üeber myelitis intrafunicularis und über kombinierte Stranger-krankung bei Alcoholismus chronicus: Kasuistik zur hämorrhagischen Diathese beim chronischen Alcoholismus. Monatschr $f$ Psychiat u Neurol 1906;20:497-528.

${ }^{30}$ Woltman HW, Heck FJ. Funicular degeneration of the spinal cord without pernicious anaemia. Neurologic aspects of sprue, nontropical sprue and idiopathic steatorrhoea. Arch Int Med 1937;60:272-300.

${ }^{31}$ Liversedge LA, Rawson MD. Myelopathy in hepatic disease and portosystemic venous anastomosis. Lancet 1966;1:277-9.

${ }^{32}$ Howard L, Wagner C, Schenker S. Thiamine in folate deficient rats. $J$ Nutrition 1974;104:1024-32.

${ }^{33}$ Thomson AD, Baker H, Leevy CM. Folate-induced malabsorption of thiamine. Gastroenterology 1971;60:756.

${ }^{34}$ Bachevalier J, Botez MI, Maag U. Learning deficits in folate-deficient rats reversible with folic acid or thiamine replacement therapy. Nutrition Reports International 1981;23:617-27.

${ }^{35}$ Spector R, Coakley G, Blakely R. Methionine recycling in brain; a role for folate and vitamin $B_{12}$. J Neurochem 1980;34:132-7.

${ }^{36}$ Scott JM, Wilson P, Dinn JJ, Weir DG. Pathogenesis of subacute combined degeneration: a result of methyl group deficiency. Lancet 1981;ii:334-7.

${ }^{37}$ Jacobsen W, Gandy G. An induced neurological disease in mice-possibly a model for subacute combined degeneration of the cord. In: Benham PD, Rose FC, eds. Progress in Neurological Research. Pitman Medical, 1979:211-22.

${ }^{38}$ Chanarin I. The Megaloblastic Anaemias. 2nd ed. Oxford: Blackwell Scientific Publications, 1979.

${ }^{39}$ Reynolds EH. The neurology of vitamin $B_{12}$ deficiency. Lancet 1976;ii:832-3. 